\title{
The Induction of Meningeal Inflammation by Components of the Pneumococcal Cell Wall
}

\author{
Elaine Tuomanen, Hans Liu, Bruno Hengstler, Oto \\ Zak, and Alexander Tomasz
}

\author{
From the Laboratory of Microbiology, The Rockefeller \\ University, New York; and the Research Department, \\ Pharmaceuticals Division, CIBA-GEIGY,
}

Basel, Switzerland

\begin{abstract}
Pneumococcal cell wall induces meningeal inflammation in rabbits injected intracisternally with $>10^{5}$ cell equivalents. Both of the major cell wall components, teichoic acid and peptidoglycan, contribute to this inflammatory activity although responses differ depending on the chemical nature, size, and complexity of these fractions. Challenge with teichoic acid (membrane or wall associated) results in greater inflammation at $5 \mathrm{hr}$ than at $24 \mathrm{hr}$. Degraded teichoic acid is inactive. In contrast, the inflammation caused by whole cell wall or high-molecular-weight peptidoglycan-containing fractions increases in intensity from 5 to $24 \mathrm{hr}$. Peptidoglycan fractions lose activity at $24 \mathrm{hr}$ when hydrolyzed to disaccharide-stem peptide moieties. Generation of free cell wall components in cerebrospinal fluid as, for example, during treatment with antibiotics that are bacteriolytic as well as bactericidal, could contribute to increased inflammation in the subarachnoid space.
\end{abstract}

The cell wall of pneumococci, located under a layer of capsular polysaccharide, remains surprisingly accessible to and reactive with the host environment [1]. We have shown that meningeal inflammation in rabbits is induced when whole pneumococci, with or without capsular polysaccharide, reach a density of $>10^{5} \mathrm{cfu} / \mathrm{ml}$ of CSF. This inflammatory response is remarkably similar to the inflammation following challenge with $10^{5}$ cell equivalents of isolated cell wall, but not of isolated capsule [2]. Because the cell wall is a complex macromolecule with many possible sites of interaction with several host defense systems, the identification of which cell wall component(s) is active in inducing inflammation during pneumococcal meningitis is of considerable importance.

The pneumococcal cell wall is composed of two major polymers: a peptidoglycan and a ribitolphosphate teichoic acid of unusually complex structure that contains phosphorylcholine [3]. The inter-

Received for publication September 17, 1984, and in revised form November 29, 1984.

This work was supported in part by a Parker B. Francis Fellowship to E. T. and by grants no. R01-AI-16794 from the National Institute of Allergy and Infectious Diseases and no. BRSGSO-7-RR-07065 from the National Institutes of Health.

We thank Drs. H. F. Chambers, M. Taueber, A. L. Smith, and M. Chase for review of the manuscript; and M. Geller for secretarial assistance.

Please address requests for reprints to Dr. Elaine Tuomanen, The Rockefeller University, Box 152, 1230 York Avenue, New York, New York 10021 action of C-reactive protein and of certain myeloma proteins with pneumococci occurs through the recognition of the teichoic acid-choline residues [4]. The teichoic acid component of the pneumococcal cell wall can also trigger the alternative pathway of complement activation in vitro [5], while both teichoic acid and peptidoglycan seem to have the capacity to bind the $\mathrm{C} 3 \mathrm{~b}$ component of complement [6].

It is not known which elements of the complex structure of the cell wall are responsible for the various interactions between the pneumococcus and the invaded host in vivo. The studies to be described here represent an attempt to answer this question in the case of the host response characteristic of pneumococcal meningitis. We tested whole pneumococcal cell wall and various biochemically defined macromolecular components of the cell wall for specific activity in provoking an inflammatory response when introduced intracisternally into the subarachnoid space of rabbits.

\section{Materials and Methods}

Streptococcus pneumoniae. Strain $\mathrm{A}_{I I}$ is an encapsulated Rockefeller University laboratory strain (type II). Strains $R_{6}$ and lyt 4-4 (an autolysin-deficient tolerant transformant of strain $R_{6}$ ) are unencapsulated strains originally derived from strain $\mathrm{A}_{\mathrm{II}}$.

Meningitis model. Male chinchilla rabbits weighing $2 \mathrm{~kg}$ (Thome Farm, Biebarach der Riss, Federal Republic of Germany) were prepared according to 
the method of Dacey and Sande [7] as described previously [2]. Unless otherwise noted, a set of four rabbits was tested for each bacteria or bacterial component inoculated. Each component was compared for activity on a cell equivalent and on a weight basis. Immediately upon withdrawal, CSF samples were analyzed for cfu and cytochemistry as described elsewhere [2].

Preparation of pneumococcal cell surface components. The preparation of a wide variety of cell surface components is described in the following sections. Because small variations in preparative techniques can yield components of significantly different natures, preparative methods are described in detail. Figure 1 schematically depicts these cell wall products.

1. Capsular polysaccharide. Several chemically different pneumococcal capsular polysaccharides were used. The polyvalent (14) pneumococcal polysaccharide vaccine (Pneumovax ${ }^{\circledR}$; Merck Sharp \& Dohme, Rahway, NJ) and type II and type III cap-

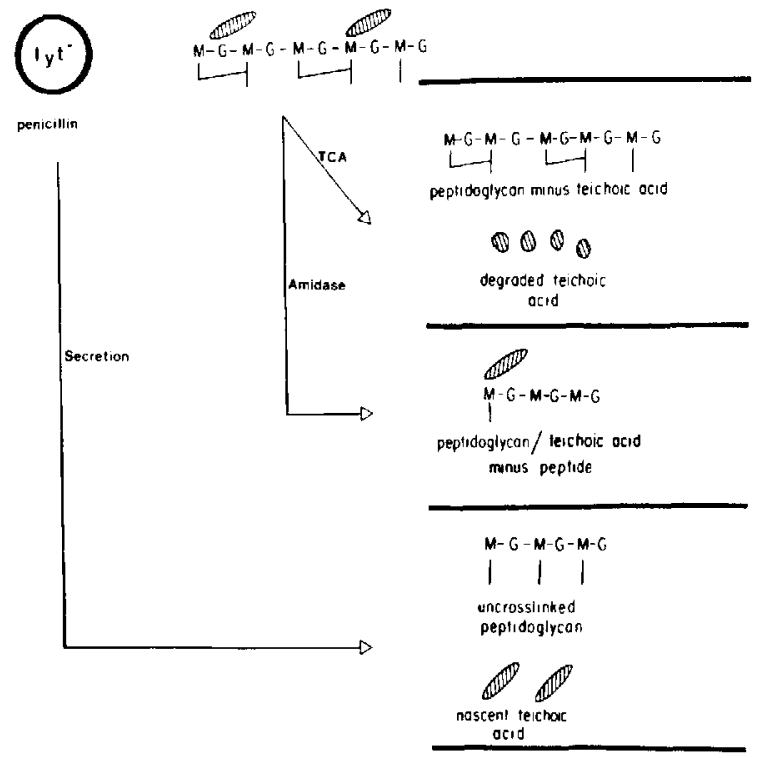

Figure 1. Summary of pneumococcal surface components that were isolated as described in Materials and Methods. Preparation $\mathrm{H}$ consists of disaccharide pentapeptide subunits derived from lysozyme treatment of preparation G. G $=N$-acetylglucosamine; $\mathbf{M}=N$ acetylmuramic acid; hatched area = teichoic acid; = stem peptide; $\mathrm{TCA}=$ trichloroacetic acid extraction; amidase $=$ treatment with $N$-acetylmuramic acid-Lalanine amidase; lyt $^{-}=$pneumococcus deficient in endogenous amidase activity; secretion = components secreted into medium upon treatment of strain lyt 4-4 with $0.024 \mu \mathrm{g}$ of penicillin $/ \mathrm{ml}$. sular polysaccharides (Merck) were each dissolved in pyrogen-free saline at concentrations of 2-5 $\mathrm{mg} / \mathrm{ml}$ and were dialyzed against several changes of the same solution. (Dialysis membrane was prepared by boiling, soaking in $0.5 M$ EDTA, and then rinsing in pyrogen-free saline.)

2. Pneumococcal cell wall. Cell wall with choline-containing teichoic acids (preparation A). Strain $\mathbf{R}_{6}$ was grown in one-liter batches of a chemically defined medium [8] to a cell concentration of $\sim 5 \times 10^{8} \mathrm{cfu} / \mathrm{ml}$. The cells were harvested by centrifugation and resuspended in $5 \mathrm{ml}$ of saline, and the resulting suspension was submerged in a boiling water bath for $15 \mathrm{~min}$ to inactivate the autolytic enzyme. The suspension was then transferred to a cuvette of the Mickle disintegrator (Hampton, Middlesex, England) mixed with an equal volume of glass beads (Ballotini no. 13; 100- $\mu \mathrm{m}$ diameter; 3M, St. Paul, Minnesota), and shaken at maximum amplitude at $4 \mathrm{C}$ for $3 \mathrm{hr}$. An airspace equal to the total volume of the suspension was kept in the cuvettes to allow efficient disruption. Next, the glass beads were separated out by sedimentation, the suspension was centrifuged at $3,000 \mathrm{~g}$ for $3 \mathrm{~min}$ (Sorvall RC2B; Sorvall, Newtown, Conn) to remove unbroken cells, and the supernatant was centrifuged at $10,000 \mathrm{~g}$ for 30 min to sediment out the cell wall material. Inspection by phase-contrast microscopy revealed only amorphous debris in such preparations. This crude cell wall material was extracted with $2 \%$ SDS at 90-100 C for $30 \mathrm{~min}$. Detergent was removed with six cycles of washings by centrifugation in distilled water. The cells, resuspended in $0.1 \mathrm{M}$ Tris-HCl buffer ( $\mathrm{pH} 8.0$ ) containing $1 \mathrm{mMMgCl}$, were treated at $37 \mathrm{C}$ with pancreatic DNase I $(50 \mu \mathrm{g} / \mathrm{ml})$ plus RNase $(100 \mu \mathrm{g} / \mathrm{ml})$ for $2 \mathrm{hr}$ followed by trypsin (100 $\mu \mathrm{g} / \mathrm{ml}$ ) plus $10 \mathrm{mM} \mathrm{CaCl}$ for $10-12 \mathrm{hr}$. (All enzyme preparations were of crystalline grade and were obtained from Worthington Biochemicals, Freehold, NJ.) Cell wall was sedimented by centrifugation $(10,000 \mathrm{~g}$ for $30 \mathrm{~min})$ and resuspended in $5 \mathrm{ml}$ of $2 \%$ SDS at $90-100 \mathrm{C}$ in a water bath for $30 \mathrm{~min}$. Detergent was removed by eight to 10 cycles of washing, first in $1 \mathrm{M} \mathrm{NaCl}$ solution and then in distilled water, and the purified wall was lyophilized. The composition of this cell wall material has been described [9].

On occasion, the following additional steps of purification were introduced. Cell wall $(10 \mathrm{mg})$ was extracted with $10-\mathrm{ml}$ portions of the following reagents at room temperature for $30 \mathrm{~min}$ each: $0.1 \mathrm{M}$ 
EDTA, $8 M \mathrm{LiCl}$ solution, and finally, acetone. Cell wall was washed with six cycles of distilled water and relyophilized.

Cell wall with ethanolamine-containing teichoic acid (preparation B). Ethanolamine-containing cell wall was prepared by the same procedure described above except that the bacteria were grown in medium in which the normal choline component $(5 \mu \mathrm{g} / \mathrm{ml})$ was replaced by ethanolamine $(20 \mu \mathrm{g} / \mathrm{ml})$. Such pneumococci produce cell wall in which the choline component of teichoic acid is biosynthetically replaced by ethanolamine [10].

Peptidoglycan free of teichoic acid (preparation C). Pneumococcal cell wall $(10 \mathrm{mg})$ was extracted with $5 \mathrm{ml}$ of $5 \%$ trichloroacetic acid (TCA) at $100 \mathrm{C}$ for $30 \mathrm{~min}$. This procedure resulted in the complete solubilization (and degradation) of cell wall teichoic acid with only $\sim 10 \%$ of peptidoglycan released [9]. Insoluble peptidoglycan was separated by centrifugation, washed with eight changes $(10 \mathrm{ml}$ each) of distilled water, and lyophilized.

Degraded cell wall teichoic acid (preparation D). The TCA extract described above (preparation C) contained teichoic acid in degraded form, as evidenced by its heterogeneity and lower molecular size [9]. The extract was shaken with an equal volume of ethyl ether to remove TCA. The water-phase (4.5 $\mathrm{ml}$ ) was then dialyzed against four liters of distilled water for two days and finally lyophilized.

Radioactively labeled cell wall (preparation E). Strain $\mathrm{R}_{6}$ was grown in the chemically defined medium supplemented with either $\left[{ }^{3} \mathrm{H}\right]$ methyl choline $\left(2 \mu \mathrm{Ci}\right.$ and $5 \mu \mathrm{g} / \mathrm{ml}$ of medium) or $\mathrm{L}-\left[4,5^{3} \mathrm{H}\right] \mathrm{ly}-$ sine $(5 \mu \mathrm{Ci}$ and $22 \mu \mathrm{g} / \mathrm{ml}$ of medium). Cell wall was prepared as described in preparation $\mathrm{A}$ above. The specific radioactivities were in the range of 5.0-7.0 $\mu \mathrm{Ci} / \mathrm{mg}$ of the dry weight of the cell walls.

3. Cell wall degradation products. Amidase product: peptide-poor glycan-teichoic acid complex (preparation F). Two batches of pneumococcal cell wall ( $80 \mathrm{mg}$ of preparation $\mathrm{A}$ ) were each resuspended in $3.5 \mathrm{ml}$ of saline containing $10 \mathrm{mM}$ of $\mathrm{K}_{2} \mathrm{HPO}_{4}$ (pH 7.4; SP). One batch received $100 \mu l\left[{ }^{3} \mathrm{H}\right]$ methyl choline-labeled cell wall $\left(\sim 10^{5} \mathrm{cpm}\right.$ total) and the other, $100 \mu \mathrm{l}\left[{ }^{3} \mathrm{H}\right]$ lysine-labeled cell wall as tracers. Each suspension received $0.3 \mu \mathrm{g}$ of pneumococcal autolysin ( $400 \mu \mathrm{l}$ containing approximately four units of enzyme activity) prepared by a previously published procedure [10]. The suspensions were incubated at $30 \mathrm{C}$ for $48 \mathrm{hr}$ during which time enzymatic solubilization was monitored [11].
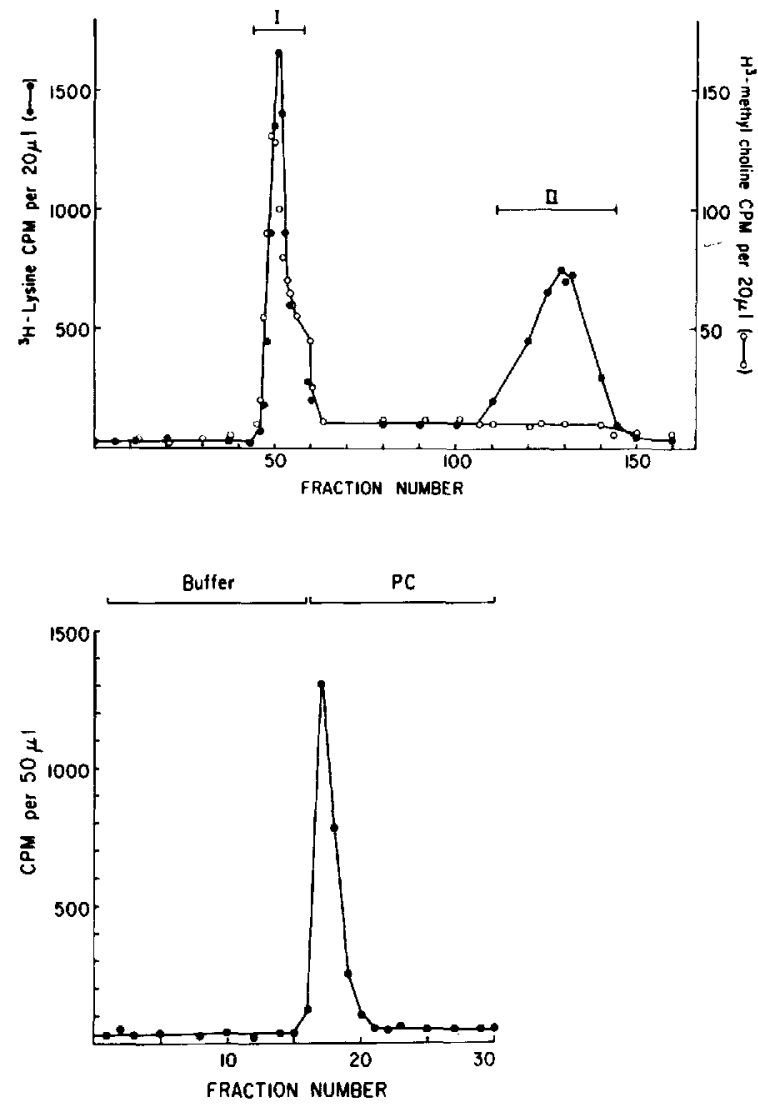

Figure 2. Top: Elution profile of the products of amidase activity on pneumococcal cell wall. Cell wall was hydrolyzed with $N$-acetylmuramic acid-I-alanine amidase and prepared as described in Materials and Methods. Peak I (fractions 46-60) represents high-molecular-weight glycan containing all the cell wall teichoic acid (labeled with $\left[{ }^{3} \mathrm{H}\right]$ methyl choline; $O$ ), as well as glycan with residual peptides (labeled with $\left[{ }^{3} \mathrm{H}\right]$ lysine; 9 ). Peak II (fractions 105-150) represents lower molecular-weight peptides released from the cell wall by the amidase (labeled with $\left[{ }^{3} \mathrm{H}\right]$ lysine only). Bottom: Elution profile of purified Forssman antigen. Partially purified $\left[{ }^{3} \mathrm{H}\right]$ methyl choline-labeled Forssman antigen was passed through a Sepharose-TEPC 15 myeloma protein affinity column as described in Materials and Methods. Because the Forssman antigen was retained on the column through its phosphorylcholine residue, impurities could be removed by washes with buffer (no $\left[{ }^{3} \mathrm{H}\right]$ methyl choline appears in fractions 1-15). Purified Forssman antigen was specifically eluted from the column upon the addition of phosphorylcholine (PC) to the eluting buffer $\left(\left[{ }^{3} \mathrm{H}\right]\right.$ methyl choline appears in fractions 17-21).

Pneumococcal autolysin is an $\mathrm{N}$-acetylmuramic acid-I-alanine amidase capable of degrading pneumococcal cell wall to two types of components separable on the basis of their different molecular sizes; the first, a high-molecular-weight glycan- 
teichoic acid complex containing all the cell wall teichoic acid and glycan with some of the stem peptides still attached and second, a lower molecularweight mixture of most of the cell wall peptides [9-11]. Cell wall hydrolysates were centrifuged $(15,000 \mathrm{~g}$ for $30 \mathrm{~min})$ and the supernatants lyophilized, then dissolved in $1 \mathrm{ml}$ of saline and layered on a G75 Sephadex column (Pharmacia Fine Chemicals, Piscataway, NJ; $2.5 \times 40 \mathrm{~cm}$ ) that was then eluted with saline (flow rate, $60 \mathrm{ml} / \mathrm{hr}$; fraction size, $1.2 \mathrm{ml}$ ). The void volume was determined by blue dextran, and $100-\mu \mathrm{l}$ portions of the fractions were assayed for radioactivity in $4 \mathrm{ml}$ of Ultraflour ${ }^{\circledast}$ by using a scintillation spectrophotometer (Nuclear Chicago, Hartsdale, NY). Figure 2 (top) shows the elution profile. Fractions $40-60$, representing the high-molecular-weight glycan-teichoic acid complex (peak I) were pooled, lyophilized, dissolved in distilled water, desalted by passing through a column of Sephadex G-10 $(2.5 \times 30 \mathrm{~cm})$, and lyophilized (yield, $11.91 \mathrm{mg}$ ).

Peptidoglycan oligomers free of teichoic acid (preparation G). Strain lyt 4-4 was grown in the synthetic medium supplemented with yeast extract [8]. At the cell concentration of $10^{8} \mathrm{cfu} / \mathrm{ml}$, the bacteria were filtered (Millipore, Bedford, Mass; $0.45-\mu \mathrm{m}$ pore size) and resuspended in the same volume of prewarmed, chemically defined medium [12] modified by omission of leucine, a nutritionally essential amino acid for pneumococci. Another modification was the lowering of the concentration of lysine from $230 \mu \mathrm{g}$ to $8 \mu \mathrm{g}$, as well as lowering the concentration of choline from $5 \mu \mathrm{g}$ to $1 \mu \mathrm{g} / \mathrm{ml}$. After incubation at $37 \mathrm{C}$ for $30 \mathrm{~min}$, penicillin $\mathrm{G}(0.1 \mu \mathrm{g} / \mathrm{ml})$ was added. Fifteen minutes later $3 \mu \mathrm{Ci}$ of $\left[{ }^{3} \mathrm{H}\right]$ methylcholine $/ \mathrm{ml}$ were added to one portion of the culture and $3 \mu \mathrm{Ci}$ of $\left[{ }^{3} \mathrm{H}\right]$ lysine were added to another portion, and the incubation was continued for $2 \mathrm{hr}$. Bacteria were then removed by centrifugation and the supernatants sterile filtered (Millipore; $0.45-\mu \mathrm{m}$ pore size) and dialyzed extensively against distilled water at $4 \mathrm{C}$. The dialysates were concentrated by vaccuum dialysis in a collodion bag apparatus (Schleicher and Schuell, Keene, NH).

Under the experimental conditions described, pneumococci secrete into the medium two kinds of cell wall polymers: nascent uncrosslinked peptidoglycan (labeled with radioactive lysine) and nascent teichoic acid (labeled with radioactive choline) [13]. These two polymers are not covalently linked to one another, and they may be separated by affinity chro- matography on columns of Sepharose coupled with myeloma TEPC-15, an immunoglobulin with high affinity for the choline-phosphate residues that are present in the pneumococcal teichoic acid [14]. Murine ascites fluid containing TEPC-15 myeloma protein was supplied by M. Potter of the National Institutes of Allergy and Infectious Diseases (Bethesda, Md). The TEPC-15 protein was isolated by using a phosphorylcholine affinity column [15]. The myeloma protein was coupled to CNBr-activated Sepharose 4B (Pharmacia) by using a published procedure [16]. TEPC-15 Sepharose ( $5-\mathrm{ml}$ bed volume) was equilibrated with $0.1 M$ sodium borate $(\mathrm{pH} 8.0)$ containing $0.15 \mathrm{M} \mathrm{NaCl}$. The concentrated dialyzed extracts $(1 \mathrm{ml})$ were loaded onto the column and the columns were washed with the buffered borate solution. All the $\left[{ }^{3} \mathrm{H}\right]$ lysine-labeled material (peptidoglycan) was recovered in this step. The material was dialyzed against distilled water and lyophilized. Quantitative adsorption to vancomycin-Sepharose columns and additional analytical data indicate that this material was made up of strands of uncrosslinked pneumococcal peptidoglycan [13].

Lysozyme product (preparation H). Uncrosslinked pneumococcal peptidoglycan $(10 \mu \mathrm{g}$ of preparation G) was resuspended in $1 \mathrm{ml}$ of $0.1 M \mathrm{~K}_{2} \mathrm{HPO}_{4}$ buffer ( $\mathrm{pH} 7.0)$, treated with egg-white lysozyme (1 $\mu \mathrm{g}$; Sigma, St. Louis) at $37 \mathrm{C}$ for $24 \mathrm{hr}$, and used directly for intracisternal inoculation. The lysozyme-cell wall digest was tested in the rabbit model in parallel with a solution of lysozyme that was five times more concentrated $(5 \mu \mathrm{g}$ of protein $/ \mathrm{ml}$ of 0.1 $M \mathrm{~K}_{2} \mathrm{HPO}_{4}$ buffer) and that contained no cell wall.

Cell wall teichoic acid free of peptidoglycan (preparation I). $\left[{ }^{3} \mathrm{H}\right]$ Methylcholine-labeled cell wall teichoic acid was recovered from the TEPC-15 columns (preparation $\mathrm{G}$ ) in $80 \%-90 \%$ yield by specific elution with $2 \mathrm{mM}$ phosphorylcholine in the borate buffer. The elution was monitored for radioactivity by assaying $0.1-\mathrm{ml}$ fractions in $4 \mathrm{ml}$ of Ultrafluor. Analytical work with this material indicates that it is made up of a mixture of cell wall teichoic acid (free of peptidoglycan) and membrane teichoic acid (Forssman antigen), in a ratio of $\sim 1: 1$ [13]. After dialysis against distilled water, the eluates were lyophilized.

4. Forssman antigen (preparation J). Pneumococcal Forssman antigen was prepared from a 20liter culture of strain $R_{6}$ grown in synthetic medium by using a modification [17] of the original procedure of Goebel et al. [18]. A small $(100 \mathrm{ml})$ culture 

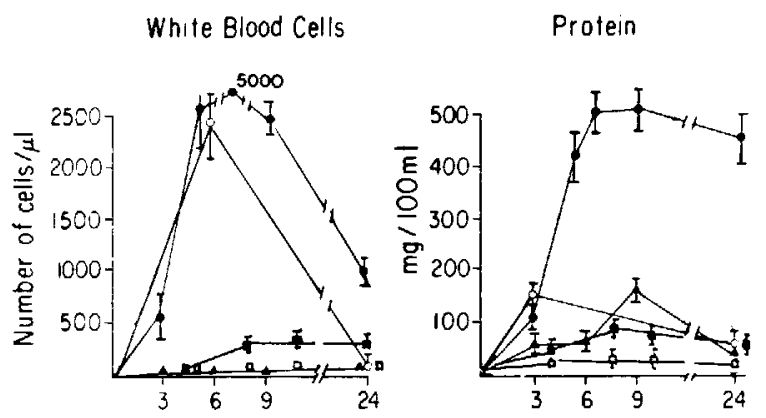

Glucose

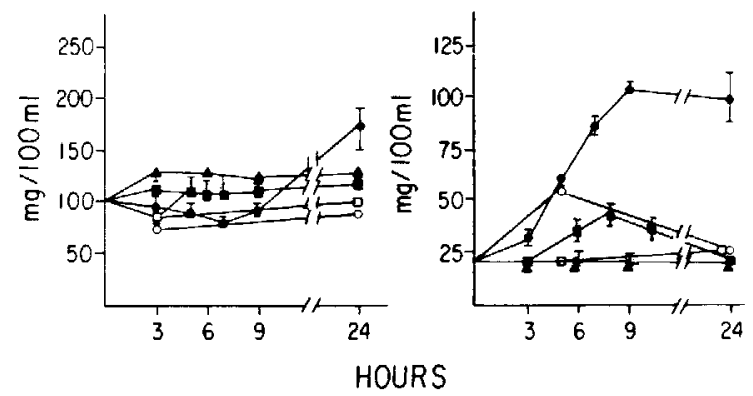

Figure 3. Titration of CSF inflammatory response to isolated cell wall and capsular polysaccharide. Groups of two rabbits were challenged with cell wall (all closed symbols) or capsular polysaccharide (all open symbols). Each component was instilled at three concentrations (suspended in $0.2 \mathrm{ml}$ saline): $2 \mathrm{mg}$ (circle), $2 \mu \mathrm{g}$ (square), $0.2 \mu \mathrm{g}$ (triangle). The CSF was then sampled over the next 24 $\mathrm{hr}$ and the cytochemistry determined as described in the text. Each point represents the mean \pm SE.

of $\mathbf{R}_{6}$ was also grown in parallel in synthetic medium containing $\left[{ }^{3} \mathrm{H}\right]$ methylcholine $(5 \mu \mathrm{Ci}$ and $5 \mu \mathrm{g} / \mathrm{ml}$ of medium) for use as a tracer in the purification of the choline-containing Forssman antigen. The pelleted bacteria from this culture were pooled with the pellet of the 20-liter culture at the beginning of the extraction procedure. The final water extract yielded $9 \mathrm{mg}$ of dry material, out of which $\sim 2.6 \mathrm{mg}$ was protein. Most of this protein impurity was removed during passage of the material $(4.5 \mathrm{mg}$ in 1.5 $\mathrm{ml} \mathrm{SP}$ ) through a Sepharose-myeloma TEPC-15 protein affinity column $(8 \mathrm{ml})$. After washing the column with 3.5 bed volumes of SP, the Forssman antigen was eluted with $10 \mathrm{ml}$ of SP containing 5 $\mathrm{m} M$ phosphorylcholine. Elution was monitored by determining radioactivity in the eluant (figure 2, bottom). Fractions 17-21 were pooled and, after extensive dialysis against distilled water, the material was lyophilized (yield, $1.5 \mathrm{mg}$ of dry material).

\section{Results}

Titration of inflammatory activity of purified pneumococcal cell wall and capsular polysaccharide. The CSF cytochemical profile induced by pneumococcal cell wall with choline-containing teichoic acid (preparation A) was compared with the profile obtained with capsular polysaccharide (figure 3). Both cell wall and capsular polysaccharide induced inflammatory changes in CSF at high doses ( $2 \mathrm{mg} / 0.2 \mathrm{ml} ; \sim 10^{8}$ cell equivalents). Cell wall was active, however, in doses as small as $0.2 \mu \mathrm{g} / 0.2 \mathrm{ml}$ $\left(\sim 10^{5}\right.$ cell equivalents), whereas capsular polysaccha-

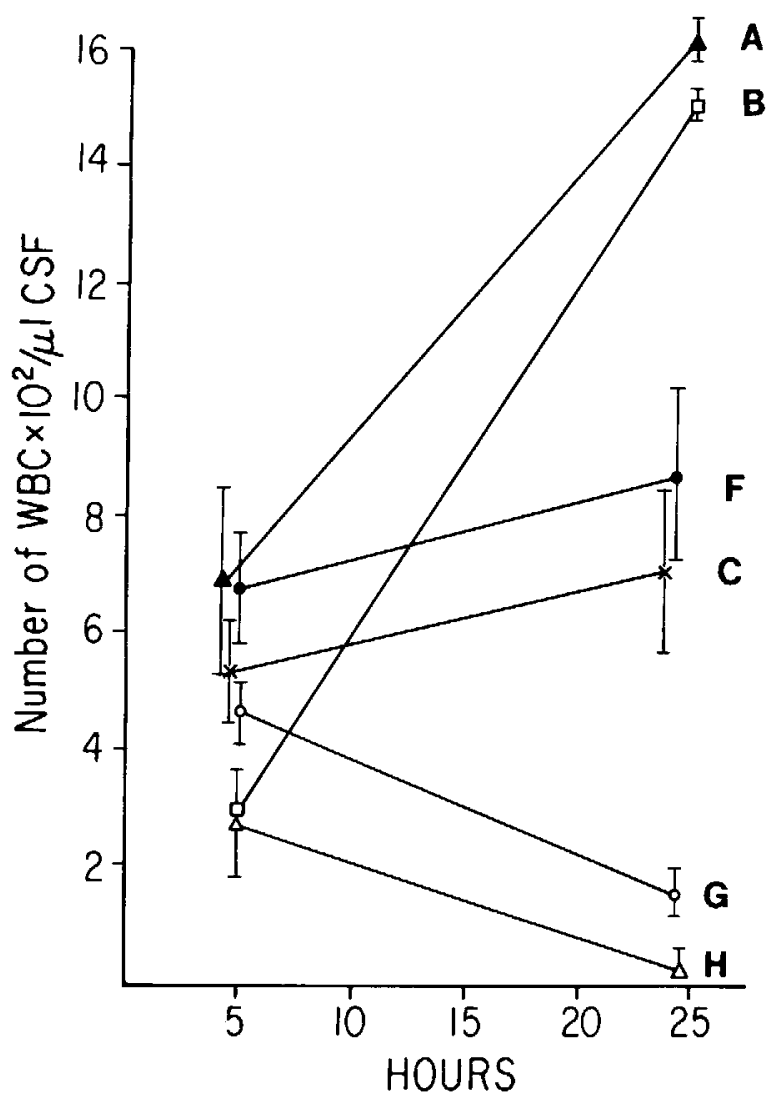

Figure 4. CSF white blood cell (WBC) response to cell wall components. A group of four rabbits was challenged with $2 \mu \mathrm{g}$ of one of the following preparations: cholinecontaining cell wall (preparation $\mathrm{A}, \boldsymbol{\Delta})$; ethanolaminecontaining cell wall (preparation $\mathrm{B}, \square$ ); amidase product (preparation $F, 0$ ); crosslinked peptidoglycan stripped of teichoic acid (preparation $\mathrm{C}, \mathrm{X}$ ); peptidoglycan oligomers without teichoic acid (preparation $\mathrm{G}, \mathrm{O}$ ); or lysozyme digest (preparation $\mathrm{H}, \Delta$ ). Lysozyme alone produced only minimal inflammation $(80 \pm 20 \mathrm{WBC} / \mu \mathrm{l})$ at $5 \mathrm{hr}$. Determinations of $\mathrm{WBC} / \mu \mathrm{l}$ of $\mathrm{CSF}$ were made as described in the text. 
ride was not active at doses of 200,20 , or $2 \mu \mathrm{g} / \mathrm{ml}$. The magnitude of the CSF leukocytosis varied directly with the concentration of cell wall introduced, e.g., leukocytes appeared both sooner and in greater number as the concentration of cell wall was raised. The minimum concentration of cell wall that could induce changes in each component of the CSF response varied: lactic acid, $20 \mu \mathrm{g} / 0.2 \mathrm{ml}$; leukocyte, $2 \mu \mathrm{g} / 0.2 \mathrm{ml}$; protein, $0.2 \mu \mathrm{g} / 0.2 \mathrm{ml}$. CSF glucose concentration failed to decrease with any nonliving inoculum.

Comparison of peptidoglycan-containing fractions of cell wall for activity in inducing CSF inflammation. All pneumococcal peptidoglycan fractions (preparations A, B, C, F, and G), regardless of size or complexity, induced a CSF inflammatory response $5 \mathrm{hr}$ after intracisternal instillation (figure 4). The initial leukocyte concentration ranged between $200-600$ cells $/ \mu \mathrm{l}$, and $>60 \%$ of these were PMNLs. The leukocyte response shifted to a predominance of lymphocytes by $24 \mathrm{hr}$ after inoculation. This is the same response observable during meningeal inflammation induced by live pneumococci. Protein and lactic acid concentrations increased in parallel with the leukocytes.

While peptidoglycan-containing fractions produced similar inflammatory responses in the first few hours after intracisternal inoculation, the evolution of inflammation over $24 \mathrm{hr}$ was quite different for the various fractions. Fractions containing large, insoluble cell wall particles were the most potent inducers of leukocytosis whether they contained choline (preparation $A$ ) or ethanolamine (preparation B; figure 4). The activity of preparation A was unchanged even when extensively purified to remove divalent cations (EDTA treatment) and adsorbed teichoic acid ( $\mathrm{LiCl}$ treatment). Removal of most of the stem peptides by amidase (as induced by penicillin; preparation F) or teichoic acid by hot TCA (preparation $\mathrm{C}$ ) reduced the magnitude of the leukocytosis. These responses to soluble cell wall fractions remained similar to whole cell wall, however, in that the leukocyte numbers were higher at $24 \mathrm{hr}$ than at $5 \mathrm{hr}$ after inoculation. Activity $24 \mathrm{hr}$ after inoculation was dramatically reduced in the case of peptidoglycan oligomers that were soluble and uncrosslinked and their lysozyme-degraded low-molecular-weight products (preparations $\mathrm{G}$ and $\mathrm{H}$ ). Thus, the larger size of the polysaccharide backbone of the peptidoglycan oligomers seemed critical to the maintenance of a CSF inflammatory response beyond $5 \mathrm{hr}$; the presence of a complete peptide network or of teichoic acid only modestly augmented this activity.

CSF inflammatory response to teichoic acid. The activity of the mixture of cell wall teichoic acid (free of peptidoglycan) and Forssman antigen (preparation I) is depicted in figure 5 . The peak of activity for teichoic acid-containing preparations was at 5 $\mathrm{hr}$ after inoculation, in contrast to $24 \mathrm{hr}$ after inoculation for peptidoglycan-containing preparations. Teichoic acid proved to have the highest specific activity of all cell wall fractions on a weight basis. CSF leukocyte density $5 \mathrm{hr}$ after inoculation was 10 times higher following instillation of teichoic acid than following instillation of the most active teichoic acid-free cell wall preparations. Virtually all of the activity associated with the teichoic acid was lost upon degradation to small fragments with

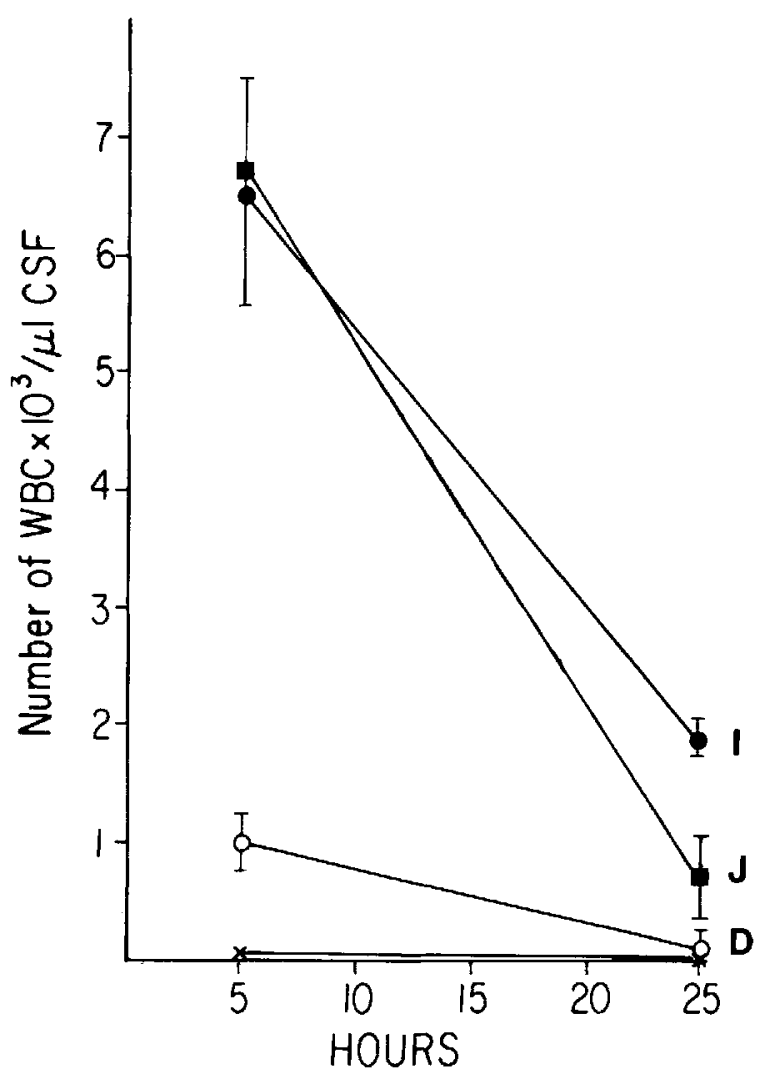

Figure 5. CSF leukocyte response to cell wall teichoic acid, membrane teichoic acid, or capsular polysaccharide. A group of four rabbits was challenged with $2 \mu \mathrm{g}$ of one of the following preparations: cell wall teichoic acid (preparation I, e); Forssman antigen (membrane teichoic acid, preparation $\mathbf{J}, \mathbf{\square}$ ); degraded teichoic acid (preparation $\mathrm{D}, \mathrm{O}$ ); or capsular polysaccharide (X). CSF determinations were made as described in Figure 4. 
hot TCA (figure 5; preparation D). Forssman antigen represents the lipid-containing membraneassociated teichoic acid. Titration of the activity of this component in the rabbit model yielded results very similar to preparation I (figure 5).

Phosphorylcholine is a characteristic component of pneumococcal teichoic acid. When this component is changed to phosphorylethanolamine several surface characteristics of the organism change, e.g., lack of daughter cell separation and sensitivity to endogenous autolysin [19]. The possibility that the reactivity of cell wall preparations in CSF would be altered by this substitution was studied by comparison of cell wall derived from organisms grown in medium containing choline or containing ethanolamine. Although ethanolamine-containing cell wall (preparation B) was less active in the initial $5 \mathrm{hr}$ of the inflammatory response, both preparations $A$ and B were equally active when assessed at $24 \mathrm{hr}(P$ $>.05$; figure 4). Thus, a specific alteration in the composition of teichoic acid had little effect on the CSF inflammatory reaction.

\section{Discussion}

Pneumococcal cell wall appears to be a potent activator of meningeal inflammation in vivo. These studies demonstrated that each of the major com- ponents of the cell wall - peptidoglycan and teichoic acid - could contribute to the induction of inflammation. Each had specific activity high enough to produce an inflammatory reaction if given at doses $\geqslant 10^{5}$ cell equivalents. In contrast, the specific inflammatory activity of capsular material was 1,000 -fold lower, a level insufficient to provoke inflammation at concentrations of capsule found in CSF during meningitis [20]. These findings are summarized in table 1.

Teichoic acid had the highest specific activity (on a weight basis) of all the cell wall fractions with the peak activity occurring $5 \mathrm{hr}$ after instillation. In contrast, peptidoglycan-containing fractions invoked increases in concentrations of CSF leukocytes, protein, and lactic acid that were greater $24 \mathrm{hr}$ after inoculation.

Inflammatory activity occurred whether the cell wall fraction was soluble or not. Activity was markedly reduced, however, if either the peptidoglycan or the teichoic acid was extensively degraded (preparations $\mathrm{H}$ and $\mathrm{D}$ ). This finding, taken together with both the high activity of the affinity-purified fractions (preparations $G, I$, and $J$ ) and the absence of activity in column effluents, strongly supports the contention that the cell wall components, and not an undefined contaminant, are responsible for inducing the inflammation.

Table 1. CSF inflammatory activity of pneumococcal surface components in a rabbit model of meningitis.

\begin{tabular}{|c|c|c|}
\hline Surface component & $\begin{array}{l}\text { Inflammatory } \\
\text { activity }\end{array}$ & Preparation \\
\hline \multicolumn{3}{|l|}{ Cell wall } \\
\hline Choline-teichoic acid & + & A \\
\hline Ethanolamine-teichoic acid & + & B \\
\hline $\begin{array}{l}\text { Without divalent cation, adsorb } \\
\text { teichoic acid, or adsorbed }\end{array}$ & + & Purified \\
\hline \multicolumn{3}{|l|}{ Without teichoic acid } \\
\hline Peptidoglycan & + & $\mathrm{C}$ \\
\hline Degraded teichoic acid & - & $\mathrm{D}$ \\
\hline Degraded peptidoglycan & -- & $\mathbf{H}$ \\
\hline Glycan-teichoic acid polymers & + & $\mathrm{F}$ \\
\hline \multicolumn{3}{|l|}{ Penicillin-treated lyt cells } \\
\hline Uncrosslinked peptidoglycan & + & $\mathrm{G}$ \\
\hline Nascent teichoic acid & + & I \\
\hline \multicolumn{3}{|l|}{ Pneumococcal plasma membrane } \\
\hline Forssman antigen & + & $\mathrm{J}$ \\
\hline \multicolumn{3}{|c|}{ Pneumococcal capsular polysaccharide } \\
\hline Pneumovax & - & $\ldots$ \\
\hline Type III & - & $\ldots$ \\
\hline
\end{tabular}

NOTE. Relative activity of surface components, $5 \mathrm{hr}$ after inoculation, in inducing abnormal CSF cytochemistry. Components were introduced at $\sim 10^{6}$ cell equivalents. $(+)=$ active; $(-)=$ inactive. 
The inflammatory activity of cell wall and several of its fractions has significant biological relevance in that these fractions could be generated in CSF during the course of meningitis. For instance, because both choline and ethanolamine are present in CSF [21], teichoic acid containing either amino alcohol could be produced during pneumococcal growth in vivo. The inflammatory activity of choline- and ethanolamine-containing cell wall are similar, however, and the course of inflammation would not be expected to change if this shift in growth conditions were to occur. Other fractions of pneumococcal cell wall could also be generated during the course of meningitis in vivo, particularly during antibiotic therapy. The peptidoglycan-teichoic acid complex produced by the action of the pneumococcal autolytic enzyme (amidase) on whole cell wall (preparation F) appears in culture supernatants following treatment of pneumococci with $\beta$-lactam antibiotics [1, 22]. This complex is also generated during spontaneous autolysis of stationary-phase cells [1]. Nascent peptidoglycan (preparation $\mathrm{G}$ ) and teichoic acid (preparation I) are secreted, unassociated with each other, during $\beta$-lactam treatment of tolerant pneumococci [13], such as the South African pneumococcal strain 8249 that is multiply resistant [23]. Forssman antigen (preparation $\mathrm{J}$ ) is readily secreted upon treatment of all pneumococci with $\beta$-lactam antibiotics [24]. It is accessible to host interactions even in living, encapsulated cells as evidenced by both the production of antibody to Forssman antigen upon challenge with whole organisms [25] and its putative role as a pneumococcal adhesin [26]. Thus, whole pneumococcal cell wall and several of its components are good candidates for initiation or augmentation of inflammation during the course of meningitis in vivo.

The mechanism whereby cell wall or cell wall fractions act as chemotaxins is as yet undefined. The inflammatory response could ensue in either of two ways: first, by activation of host defense systems that generate chemotaxins, or second, by direct interaction between cell wall and host cells.

In the first case, a likely mechanism may involve complement [27] or C-reactive protein (CRP). The alternative pathway of complement is specifically activated by teichoic acid and to a lesser extent by large peptidoglycan units $[5,6,28]$. The inflammatory response would, perhaps, be expected to appear earlier and might be more intense if complement were activated in CSF. This may explain in part the rapid onset and high-specific activity of teichoic acid-containing cell wall components. CRP has been demonstrated in CSF [29] and is known to promote complement activation by interacting with teichoic acid-associated phosphorylcholine $[4,30,31]$. The finding that cell wall containing either ethanolamine or choline produces similar inflammatory responses in rabbits is consistent with the fact that rabbit CRP reacts equally well with either of these two cell wall preparations [32]. It must be noted, however, that complement is not known to fix to small peptidoglycan units [33], yet these components are effective at inducing inflammation. In addition, CSF contains very little complement even late in the course of meningitis $[34,35]$. It would be more reasonable, therefore, to predict that while complementdependent chemotaxins may contribute to the inflammatory response in meningitis, they may not be the only mechanism for its generation.

In the second case, noncomplement-derived chemotaxins have been described in CSF $[36,37]$ and are potentially attributable to direct interaction between bacterial components themselves and host cells $[38,39]$. Cell wall could potentially interact directly with CSF monocytes and stimulate production of chemotaxins (e.g., leukotriene $B_{4}$ ) without involving complement. Preliminary data from our studies in complement-depleted animals are compatible with this hypothesis. Such an interaction presumes the existence of a receptor for cell wall components on host cells. Such a host cell receptor had been proposed to be on the surface of epithelial cells for the membrane analogue of cell wall teichoic acid - Forssman antigen [26]. It is conceivable that receptors for this amphipathic molecule or for other cell wall component(s) may be present on the meningeal membrane lining all or part of the CSF space.

Our findings strongly suggest that the inflammatory reaction in pneumococcal meningitis derives, at least in part, from component(s) of the bacterial cell wall rather than from the capsule. The generation of an inflammatory response in the course of natural infection serves to control bacterial multiplication. Our evidence suggests, however, that bacterial lytic products such as cell wall released during druginduced autolysis, may represent a reservoir of inflammatory products that could contribute to further injury to host tissues including, perhaps, mortality despite effective CSF sterilization. We suggest that exploring avenues of antibacterial therapy that are bactericidal but nonbacteriolytic may lead 
to methods of treatment that diminish the overall host inflammatory response and may, conceivably, improve the overall morbidity and mortality of pneumococcal meningitis.

\section{References}

1. Tomasz A. Surface components of Streptococcus pneumoniae. Rev Infect Dis 1981;3:190-211

2. Tuomanen E, Tomasz A, Hengstler B, Zak O. The relative role of bacterial cell wall and capsule in the induction of inflammation in pneumococcal meningitis. J Infect Dis 1985;151:535-40

3. Mosser JL, Tomasz A. Choline-containing teichoic acid as a structural component of pneumococcal cell wall and its role in sensitivity to lysis by an autolytic enzyme. J Biol Chem 1970;245:287-98

4. Szu SC, Clarke S, Robbins JB. Protection against pneumococcal infection in mice conferred by phosphocholinebinding antibodies: specificity of the phosphocholine binding and relation to several types. Infect Immun 1983;39:993-9

5. Winkelstein JA, Tomasz A. Activation of the alternative complement pathway by pneumococcal cell wall teichoic acid. J Immunol 1978;120:174-8.

6. Hummell DS, Berninger RW, Tomasz A, Winkelstein JA. The fixation of $\mathrm{C} 3 \mathrm{~b}$ to pneumococcal cell wall polymers as a result of activation of the alternative complement pathway. J Immunol 1981;127:1287-9

7. Dacey RG, Sande MA. Effect of probenecid on cerebrospinal fluid concentrations of penicillin and cephalosporin derivatives. Antimicrob Agents Chemother 1974;6:437-41

8. Lacks S, Hotchkiss RD. A study of the genetic material determining an enzyme activity in Pneumococcus. Biochim Biophys Acta 1960;39:508-18

9. Höltje JV, Tomasz A. Specific recognition of choline residues in the cell wall teichoic acid by the $\mathrm{N}$-acetylmuramyl- $\mathrm{L}$ alanine amidase of pneumococcus. J Biol Chem 1975;250:6072-6

10. Tomasz A, Westphal M, Briles EB, Fletcher P. On the physiological functions of teichoic acids. J Supramol Struct 1975;3

11. Höltje JV, Tomasz A. Purification of the pneumococcal Nacetylmuramyl-L-alanine amidase to biochemical homogeneity. J Biol Chem 1976;251:4199-207

12. Tomasz A. Studies on the competence (for genetic transformation) of Diplococcus pneumoniae using a synthetic medium. Bacteriological Proceedings 1964:29

13. Fischer $\mathbf{H}$, Tomasz A. Production and release of peptidoglycan and wall teichoic acid polymers in pneumococci treated with beta lactam antibiotics. J Bacteriol 1984;157:507-13

14. Potter M, Lieberman R. Common individual antigenic determinants in five of eight BALB/c IgA myeloma proteins that bind phosphoryl choline. J Exp Med 1970;132:737-51.

15. Chesebro B, Metzger $H$. Affinity labeling of a phosphorylcholine binding mouse myeloma protein. Biochemistry 1972;11:766-71

16. Cuatrecases $P$. Protein purification by affinity chromatography. J Biol Chem 1970;245:3059-65
17. Briles EB, Tomasz A. Pneumococcal Forssman antigen: a choline-containing lipoteichoic acid. $\mathrm{J}$ Biol Chem 1973;248:6394-7

18. Goebel WF, Shedlovsky T, Lavin GI, Adams MH. The heterophile antigen of pneumococcus. J Biol Chem 1943;148:1-15

19. Tomasz A. Biological consequences of the replacement of choline by ehtanolamine in the cell wall of pneumococcus: chain formation, loss of transformability and loss of autolysis. Proc Natl Acad Sci USA 1968;59:86-93

20. Nolan CM, Ulmer WC Jr. Enzyme immunoassay of the capsular polysaccharide of Streptococcus pneumoniae type III in cerebrospinal fluid in experimental meningitis. J Med Microbiol 1980;13:551-60

21. Letner C, ed. Geigy Scientific tables. 8th ed. Basel, Switzerland: CIBA-GEIGY, 1981:168-9

22. Tomasz A, Höltje JV. Murein hydrolases and the lytic and killing action of penicillin. In: Microbiology 1977. Washington, DC: American Society for Microbiology, 1977:209-15

23. Liu $\mathrm{H}$, Zighelboim S, Tomasz A. Penicillin tolerance in multiply drug-resistance natural isolates of Streptococcus pneumoniae [abstract no. 506]. In: Program and abstracts of the 21st Interscience Conference on Antimicrobial Agents and Chemotherapy. Washington, DC: American Society for Microbiology, 1981.

24. Horne D, Hakenbeck R, Tomasz A. Secretion of lipids induced by inhibition of peptidoglycan synthesis in streptococci. J Bacteriol 1977;132:704-17

25. Wicken AJ, Knox KW. Lipoteichoic acids: a new class of bacterial antigen. Science 1975;187:1161-7

26. Ofek I, Beachey EH, Jefferson W, Campbell GL. Cell membrane-binding properties of Group A streptococcal lipoteichoic acid. J Exp Med 1975;141:990-1003

27. Ernst JD, Hartiala KT, Goldstein IM, Sande MA. Complement (C5)-derived chemotactic activity accounts for accumlation of polymorphonuclear leukocytes in cerebrospinal fluid of rabbits with pneumococcal meningitis. Infect Immun 1984;46:81-6

28. Hummell DS, Swift AJ, Tomasz A, Winkelstein JA. Activation of the alternative complement pathway by pneumococcal lipoteichoic acid. Infect Immun 1985;47:384-7

29. Corrall CJ, Pepple JM, Moxon ER, Hughes WT. C-reactive protein in spinal fluid of children with meningitis. J Pediatr 1981;99:365-9

30. Kaplan MH, Volanakis JE. Interaction of C-reactive protein complexe; with the complement system. J Immunol 1974;112:2135-47

31. Mold C, Nakayama S, Holzer TJ, Gewurz H, du Clos TW. C-reactive protein is protective against Streptococcus pneumaniae infection in mice. $J$ Exp Med 1981;154:1703-8

32. Oliveira EB, Gotschlich EC, Liu T-Y. Comparative studies on the binding properties of human and rabbit $\mathrm{C}$-reactive proteins. J Immunol 1980;124:1396-1402

33. Dinarello CA, Elin RJ, Chedid L, Wolff SM. The pyrogenicity of the synthetic adjuvant muramyl dipeptide and two structural analogues. J Infect Dis 1978;138:760-7

34. Zwahlen A, Nydegger UE, Vaudaux P, Lambert P-H, Waldvogel FA. Complement-mediated opsonic activity in normal and infected human cerebrospinal fluid: early response during bacterial meningitis. J Infect Dis 1982;145:635-46

35. Simberkoff MS, Moldover NH, Rahal JJ Jr. Absence of de- 
tectable bactericidal and opsonic activities in normal and infected human cerebrospinal fluids. J Lab Clin Med 1980;95:362-72

36. Nolan CM, Clark RA, Beaty NH, Experimental pneumococcal meningitis. III. Chemotactic activity in cerebrospinal fluid. Proc Soc Exp Biol Med 1975;150:134-6

37. Ward PA, Lepow IH, Newman LJ. Bacterial factors chemotactic for polymorphonuclear leukocytes. Am J Pathol 1968;52:725-36
38. Peterson PK, Wilkinson BJ, Kim Y, Schmeling D, Douglas SD, Quie PG, Verhoef J. The key role of peptidoglycan in the opsonization of Staphylococcus aureus. J Clin Invest 1978;61:597-609

39. Ogawa T, Kotani S, Fukuda K, Tsukamoto Y, Mori M, Kusumoto S, Shiba T. Stimulation of migration of human monocytes by bacterial cell walls and muramyl peptides. Infect Immun 1982;38:817-24 